\title{
India's New Education Policy - an Elephant with Two Types of Teeth
}

\author{
Abhai Maurya* \\ English and Foreign Languages University \\ Hyderabad, India \\ E-mail: abhai.maurya@gmail.com
}

\begin{abstract}
India's education policy under the right wing government, presently in power in India, is replete with contradictions between hypocritical claims and ground realities. The claims are all politically correct, but the practice is contradictory to the declared claims so made. The new education policy is conservative in most respects. The emphasis is on traditions, past and conservative value system. Despite the phrases like equity, democracy and the rant against commercialization, in practice we witness subversion of all that is politically correct.
\end{abstract}

Keywords-India's education policy; new education policy; values; traditions; equity; democracy; subversion of democracy; commercialization; WTO; GATS; privatization

\section{INTRODUCTION}

There is a pithy expression to the effect that law is like a lamppost, which cannot be jumped over, but it can be bypassed. This formulation, indeed, aptly sums up the recent exercise in futility undertaken in the framework of the socalled New Education policy by the present-day rulers of our country. In 2016, a 217-page report, submitted to the Ministry of Human Resources Development (MHRD) of India by a high-powered committee headed by a former cabinet Secretary, had been put in public domain by the Chairman of the committee. The MHRD put on its official website a 43-page document titled "Some Inputs for Draft National Policy 2016". Concomitant with this there had been a large-scale pomp and show masqueraded in the garb of democratic consultations. The torrents of words, the wellorchestrated hula-bula, the media hype etc. were all sure signs of the menacing dark clouds gathering over the horizon. Paradoxically, the whole nation was to be enraptured by sweet-nothings or at best soporific pills of empty harangue and demagoguery.

\section{The NATIONAL EDUCATION POLICY 2016 POSTULATE}

The Committee's report had nine chapters each subdivided into numerous sub-sections covering almost all the aspects of India's education scenario. The MHRD's abovementioned document titled "Inputs ..." has four chapters. At the first cursory glance, the document seems to be a

*Prof. Abhai Maurya-Founder, Vice-Chancellor, English and Foreign Languages University. politically correct piece of work. But when one begins reading between the lines the contours of a gigantic hidden agenda begin to flash out every now and then. The education under Vedic System and later Gurukul system are hailed as fostering the "bond between the Guru (a teacher - AM) and Shishya (pupil - AM)". Historically, the evolution of Indian Education system is traced from Takshila in $700 \mathrm{BC}$ to Nalanda in the $4^{\text {th }}$ century AD. It is claimed: "In its heyday, in the $7^{\text {th }}$ century AD, Nalanda University had some 10,000 students and 2,000 teachers. The subjects taught at Nalanda University covered diverse fields of learning covering science, astronomy, medicine, and logic as diligently as they applied themselves to metaphysics, philosophy, Samkhya, Yoga-shastra, the Vedas, and the scriptures of Buddhism and foreign philosophy. Transcending ethnic and national boundaries, Nalanda University attracted pupils and scholars from China, Indonesia, Korea, Japan, Persia, Turkey and other parts of the world." Russia had been excluded, mercifully.

Eulogizing the contributions made by the great Indian scholars in ancient times, the formulation seems to be crossing the borders and closing the gaps. Here it is: "Indian scholars like Charaka and Susruta, Aryabhata, Bhaskaracharya, Chanakya, Patanjali and Vatsayayna and numerous others made seminal contribution to the world knowledge in such diverse fields as mathematics, astronomy, physics, chemistry, medical science and surgery, fine arts, mechanical and production technology, civil engineering and architecture, shipbuilding and navigation, sports and games." One only wonders why the tall claims about the pinnacle that ancient India had achieved in the fields of science and technology miss out the oft repeated boast that during the times of Mahabharata India had helicopter (udankhatola) and TV (Sanjay sitting at Indraprastha, i.e. modern-day Delhi, giving the live commentary to Dharitrashtra on the battles, taking place at Kurukshetra between Pandavas and Kuravas) Coming to the contribution made to Indian education by Indians during India's freedom struggle the formulation is quite interesting, euphemistically speaking: "During the freedom struggle, several leaders like Gokhale, Ram Mohan Roy, Pt. Madan Mohan Malaviya and Gandhiji worked for better education for the people of India." Obviously, Nehru, Maulana Abul Kalam Azad etc. had to be discarded to the dustbin of history, their huge contribution, notwithstanding. 
Coming to the modern stage of the evolution of Indian education policy, the document under reference recurrently highlights the communication technologies and human skills and it claims: "The National Education Policy 2016, which is designed to guide the renewal process in education in India, represents an attempt in this direction. The National Education Policy, 2016 envisions a credible education system capable of ensuring inclusive quality education and lifelong learning opportunities for all and producing students/graduates equipped with the knowledge, skills, attitudes and values that are required to lead a productive life, participate in the country's development process, respond to the requirements of the fast - changing, ever - globalising, knowledge - based societies, and developing responsible citizens who respect the Indian tradition of acceptance of diversity of India's heritage, culture and history and promote social cohesion and religious amity. This vision recognizes the central role of education in India's social, economic, political, and cultural development. Mahatma Gandhi said, "The real difficulty is that people have no idea of what education truly is. We assess the value of education in the same manner as we assess the value of land or of shares in the stock exchange market. We want to provide only such education as would enable the student to earn more. We hardly give any thought to the improvement of the character of the educated." Inspired by the thoughts of the Father of the Nation, the Policy brings into focus the role of education in inculcating values, providing skills and competencies to citizens, and enabling them to contribute to the nation's wellbeing. It recognizes that long-term economic growth and development of the nation critically depends upon the quality of the products of the education system and that an education system built on the premises of quality and equity is central to sustainable development and to achieving success in the emerging knowledge economy and society. It recognizes education as the most potent tool for socio-economic mobility and a key instrument for building an equitable, just and human society. It also recognizes the education as an integrative force in society, and its role in imparting values that foster social cohesion and national identity. The vision also implies that good quality education will help amalgamate globalization with localization, enabling India's children and youth to become global citizens, with their roots deeply embedded in Indian culture and traditions." (Italics AM)

\section{TRAPS AND PITfALls OF THE NEW EdUCATION POLICY}

The claim about "the renewal process in education in India" implies that the education in India had been dead or dormant hitherto. Hence the "renewal", which comment is self-righteous enough to be commented upon. The running thread in the document under study is provided by the phrases like "respect the Indian tradition", "knowledge, skills, attitudes and values", "global citizens, with their roots deeply embedded in Indian culture and traditions" and other shown in italics in the above quotation. Indeed, such phrases let the cat out of the bag, as they are the key to the understanding of the hidden agenda embedded deep down in the text of the document.

The document indeed is a clever piece of writing replete with right kind of clichés, altruisms and high-sounding howlers and what have you. There are elaborate formulations about the education to girls, equity, inclusive quality education, "peace, tolerance, secularism, national integration, social cohesion and mutual respect for all religions, as well as universal values" and what have you. There is also a conspicuous rant against "commercialization of education ...", against "gender, cultural and regional disparities". All the right kind of noises have been made in the document under reference.

But words are like double-edged swords. At times, they cut both ways. To drive our point home we would refer to some of the yawning hiatuses between the words and deeds. Take for example the rights of students and freedom of expression. In the document under discussion, it is stated: "The Government recognises and will encourage the positive role played by students' unions in furthering the interests of democracy and strengthening the democratic systems, governance and processes, as well as debates, discussions and pluralism of thoughts." In actual practice, however, students voicing dissent are subjected to the most brutalised suppression and oppression. For instance, at one of the most prestigious universities of India, i.e., at Jawaharlal Nehru University (JNU) the ruling party dispensation of the university has subjected the dissenting students to all kinds of persecution: rustication, stoppage of stipend, eviction from hostel, lodging of false police cases with the police against the students not toing government line, beating of innocent students by the goons of ruling party students' organization. Several victims of ruling party student bullies have been driven to suicides. Seminars, discussions on topics not to the liking of the ruling dispensation of the country are brutally suppressed and vandalized. Through strong-arm tactics, the whole national media has been bullied into submission and made to toe the ruling party line. Thus, the media is coerced to portray the dissenting students and teachers of the country in horrendously dark and devilish colours and hues. Agent provocateurs of the ruling camarilla penetrate demonstrations and protests organized by democratic students and teachers. These planted elements mouth the anti-national slogans and after playing their heinous game they disappear in thin air. The organizers are readily dubbed as antinational by the media and then the wanton police action follows against the protestors. The freedom of expression has thus practically snuffed out from the campuses yielding place to the fear, intimidation and terror prevailing now in most universities. CCTV cameras have been installed in every nook and corner of the universities. Swift action follows against anybody raising a voice of protest. It is in this background that the suicides committed by several students coming from the dalit and disadvantaged background have to be seen.

The Vice-Chancellors, appointees of the ruling party, subvert the statutory bodies, Executive Councils and Academic Councils of the universities in the most brazen manner by declaring items on agenda as passed without 
allowing any discussion on the issues involved. Such tactics had not been resorted to even during the worst period of Indian democracy, the emergency period of the 1970's. The established rules and conventions for constituting the selection committees for appointment of teachers are being given a short shrift as the Vice-Chancellors have been using their emergency powers and packing the selection committees with hand-picked ruling party agents with a view to get the candidates of the ruling party appointed to teaching positions. The lack of democracy has hit the lowest ebbs and a sense of utter despondency and helplessness has engulfed most universities in the country.

There are eloquent words in the document about equity and social justice. But what is happening in reality? Dalits students are forced to commit suicide by the students-goons of the ruling party. In Central University, Hyderabad not only Rohit Vemula, a dalit student was forced to commit suicide, his mother, his brother were subjected to the most vulgar type of vilification campaign. Their crime was that they had been demanding justice for their murdered son.

The voice of students coming from disadvantaged background had been gaining ground in Indian universities over several decades in the nearest past. With a view to snuff out their voices Government hit upon a clever ploy. It started implementing an undeclared decision to curtail the admission of disadvantaged students to the universities. In JNU, for example. The deprivation points that had been won through hard-fought struggles in the past for disadvantaged background students have been withdrawn lock, stock and barrel. The number of seats in subjects of humanities and social sciences, which is where most of the disadvantaged students used get admission, have been reduced several times over. That is how equity in education is sought to be achieved.

The document under discussion opens the discussion on "Curriculum Renewal ..." with the following quotation from Swami Vivekananda, "Education is not the amount of information that we put into your brain and runs riot there, undigested, all your life. We must have life-building, manmaking, character-making assimilation of ideas. If you have assimilated five ideas and made them your life and character, you have more education than any man who has got by heart a whole library ... If education is identical with information, the libraries are the greatest sages of the world and encyclopaedia are the greatest Rishis." From here stems the obsession with the creation of "value-based education" capable of becoming a source of education that would "impart skills which can contribute to man-making and nation-building". Now for making the education a "valuebased" system leading to the acquisition of relevant skills renewal of curricula becomes a key imperative. In this scheme of things acquisition of knowledge through education stands relegated to a secondary position. Apart from the inculcation of skills, the value system will be fostered through intensive and extensive teaching of Sanskrit, considered to be vehicle of retrograde value-system and cultural practices based on tradition and religious fanaticism stemming from mechanical ritualism and blind faith in cultism or irrational practices. If the masses remain mired in the cobwebs of religious bigotry and blind faiths so much the better for the ruling dispensation. It is by keeping the hapless masses entangled in the cobwebs of the most retrograde cultural or religious practices that the present rulers can perpetuate their rule. Marx's dictum to the effect that religion is the opium of the people stands vindicated.

Regardless of the rant against commercialization of education, in practice the commercialization is having a hay day under the policies of powers that be. In a calculated manner, the government school education has been subverted without any hopes of its redemption. The space of government schools has been usurped by private schools, which are beyond the reach of majority of Indian masses due to the exorbitantly high fees and other costs. Thus, the school education stands totally commercialized.

Of late private universities have been mushrooming with a whirlwind speed. The irrefutable logic should demand the subversion of state university system in the country, which what has been happening gradually but irreversibly for the last decade or so. This phenomenon has gathered a whirlwind momentum under the present regime. Notwithstanding the sooth sayings about the raising of financial allocations for education to $6 \%$ of the GDP, the state educational institutions are being starved of funds forcing the institutions to fend for themselves. This is compelling the educational institutions to raise fees, privatise their services and in the process become out of reach for the majority of Indian people. The claims of equity and rants against commercialization are completely hollow meant to hoodwink the gullible.

The knowledge has been declared to be a tradable commodity and education a mercantile service, which is what was sought to be done by the government of India, when in 2005 it 'made an 'offer' to provide Market Access to higher education as a 'tradable service' under the World Trade Organisation's (WTO) General Agreement of Trade in Services (GATS)" (Madhu Prasad, Knowledge as Trade: Higher Education and WTO-GAT Regime). According to a position paper titled "Trade in Higher Education: Impact of GATS on Higher Education, Research and Knowledge Systems in Selected Contexts in Asia and the Asia Pacific Region", presented at UNESCO's Second regional meeting in 2000 by Prof Nigvekar, then UGC Chairperson and a present ruling part protegee, it was declared that knowledge had become a "tradeable commodity". Nigvekar further declared that there was "little if any empirical evidence that GATS and the trade in education service per se is compromising national systems of higher education".

\section{CONCLUSION}

Now the logic of the knowledge being declared a tradeable commodity and the education a service is that India is bound by the conditions of GATS which prohibits any kind of subsidy or concessions given to any group of students, advantaged or disadvantaged in financing higher education. This inexorably leads to the wholesale commercialization of higher education, making it inaccessible to large mass of Indian aspirants for university 
education: "Due to the commercialization of services, the architecture of GATS is more complex than the architecture of trade agreements on goods. Four modes of trade in services have been demarcated. These are: (1) Cross-border supply: provision of a service at a distance. In the case of education, this mode includes e-learning or other distance learning programs. (2) Consumption abroad: the consumerstudent travels to another country to access the service. (3) Commercial presence: the service company sets up a subsidiary abroad. For example, a university sets up a campus abroad. (4) Presence of natural persons: a professional (researcher or teacher) travels to a foreign country to provide a service. Markets may be opened in one or more of these modes." All these provide for possibilities for GATS to run riot with Indian Education system. In particular WTO's and GATS' rules demand level playing fields for national and foreign universities, which essentially means that no government subsidies could be given to Indian universities that are not available to foreign universities.

Acceptance of WTO/ GATS dispensation means snuffing out of all subsidies being given to education system in India. This for all practical purposes closes the doors of higher education for economically disadvantaged students, making education an exclusive domain of elite class. Such a scenario is pregnant with turmoil and turbulence in the entire Indian society capable of causing grievous injury to India's social fabric. 